\title{
Ultrastructure of white spot syndrome virus development in primary lymphoid organ cell cultures
}

\author{
Chung-Hsiung Wang ${ }^{1}$, Hsi-Nan Yang ${ }^{2}$, Chih-Yuan Tang ${ }^{2}$, Chien-Hsin Lu ${ }^{1}$, \\ Guang-Hsiung $\mathrm{Kou}^{2}$, Chu-Fang $\mathrm{Lo}^{2, *}$ \\ ${ }^{1}$ Department of Entomology, National Taiwan University, Taipei, Taiwan 106, ROC \\ ${ }^{2}$ Department of Zoology, National Taiwan University, Taipei, Taiwan 106, ROC
}

\begin{abstract}
Primary cell cultures from the lymphoid organ of Penaeus monodon were used to investigate in vitro propagation and morphogenesis of white spot syndrome virus (WSSV). Double-strength Leibovitz's L15 supplemented with $20 \%$ fetal bovine serum, pH 7.5, with a final osmolarity of $530 \pm$ $5 \mathrm{mOsm} \mathrm{kg}^{-1}$ was identified as the most suitable culture medium. In this medium, the lymphoid cells remained viable for more than $1 \mathrm{wk}$. Migrating cells were inoculated with WSSV, and the consequent cytopathic effects documented by light and electron microscopy. WSSV appears capable of following 2 alternative assembly sequences, one similar to the morphogenesis of the Oryctes rhinocerus virus and another which is more typical of baculoviral assembly. Possible relationships between WSSV, Oryctes virus, and baculoviruses are discussed.
\end{abstract}

KEY WORDS: WSSV $\cdot$ In vitro propagation $\cdot$ Lymphoid cells

\section{INTRODUCTION}

White spot syndrome (WSS) is a viral disease which affects most of the commercially cultivated marine shrimp species, not just in Asia but globally (Takahashi et al. 1994, Chou et al. 1995, Wongteerasupaya et al. 1995, Lightner 1996, Lo et al. 1996a,b, Flegel 1997). In Taiwan, WSS was first identified in 1992, and since then outbreaks of the disease have occurred every year. These outbreaks can cause up to $100 \%$ mortality in populations of cultured shrimp and they have a correspondingly devastating economic impact. The disease is characterized by obvious white spots on the carapace, appendages, and the inside surface of the body. So far no significant resistance to this disease has been reported for any species of shrimp.

The causative agent of WSS, white spot syndrome virus (WSSV), is a rod-shaped crustacean virus (Chou

•Corresponding author. E-mail: gracelow@ccms.ntu.edu.tw et al. 1995, Wang et al. 1995, Lo et al. 1996b). WSSV has a wide host range and targets various tissues (Chang et al. 1996, Lo et al. 1996a, 1997b). The rapid onset and lethality of this disease are remarkable (Chou et al. 1995, Chang et al. 1996). The virion is fusiform or rod-shaped with bluntly rounded ends. In negatively stained preparations, it is 70 to $150 \mathrm{~nm} \times$ 250 to $380 \mathrm{~nm}$ (width $\times$ length). In some virions, a taillike projection can be seen extending from one end (Wang et al. 1995).

In an earlier paper (Wang et al. 1995), we showed that in several respects, including viral morphology and genome size, WSSV shares characteristics with OrV (Oryctes rhinoceros virus), a pathogenic, nonoccluded virus (NOV) of the coleopteran insects in the family Scarabeidae, and especially OrV of the palm rhinoceros beetle O. rhinoceros (Huger \& Krieg 1991, Crawford 1994). On the other hand, based on other characteristics, WSSV is quite different from HZ-1, another NOV. Prior to 1981, OrV was a member of the family Baculoviridae (Bedford 1981), but in 1995 the 
taxonomic position of the NOVs was changed, so that OrV and the other NOVs are now classified as unassigned invertebrate viruses (Murphy et al. 1995). The taxonomic position of WSSV is also unclear because of the limited amount of basic data available regarding its replication, genome organization, genome sequencing, gene order and other genetic considerations. Thus, it remains uncertain whether WSSV will ultimately be included in the Baculoviridae or not. As a first step towards resolving this question, we report here on the propagation of WSSV in shrimp cells primary cultures. The successful development of primary cell culture has recently been reported in many laboratories (Hsu et al. 1995, Lu et al. 1995a,b, Loh et al. 1997. Tapay et al. 1997) and has proven useful for studying shrimp viruses in vitro (Flegei 1997, Tapay et al. 1997. Kasornchandra \& Boonyaratpalin 1998). Loh et al. (1998) developed and used primary lymphoid cell culture systems for quantal assay of shrimp viruses, evaluation of viral inhibitors, and synthesis of viral proteins. Kasornchandra \& Boonyaratpalin (1998) used primary shrimp cell cultures for propagation of WSSV, for a viral titration assay, for determining WSSV tissue and organ specificity in Penaeus monodon, and for determining the relative virulence of WSSV to various species of crustaceans. However, although numerous attempts have been made, no WSSV-susceptible continuous shrimp cell line has yet been established. In this paper, we therefore used primary culture of the lymphoid organ of $P$. monodon to study the in vitro propagation of WSSV. We also compare intracellular viral assembly between WSSV and OrV in an attempt to identify any differences in morphogenesis.

\section{MATERIALS AND METHODS}

Shrimp and primary culture of lymphoid organ cells. In the present study, 2-step WSSV diagnostic PCR (polymerase chain reaction), a highly specific and sensitive technique which uses nested primer sets derived from the sequence of a cloned WSSV Sal I 1461 bp DNA fragment (Lo et al. 1996b), was used to test for the presence/absence of WSSV. The live subadult and adult Penaeus monodon used in each experiment were all 2-step WSSV PCR negative. Shrimp were anesthetized by being placed on ice and were surface-sterilized with $70 \%$ alcohol followed by $0.02 \%$ iodine disinfectant before tissue excision

Excised lymphoid organs were separated into small fragments using sterilized forceps and then incubated with $4 \mathrm{ml}$ complete medium in $25 \mathrm{~cm}^{2}$ flasks or on coverslips at $28^{\circ} \mathrm{C}$. Confluent cells appeared about $24 \mathrm{~h}$ after seeding. At this time, the original medium, which now contained unattached tissues, was removed, fresh medium was added, and the culture was inoculated with virus.

Culture media. The basic media tested were NCTC135 medium (NCTC), Leibovitz's L15 medium (L15) and modified Grace's Insect medium (TNM-FH). The parameters of all of these media were modified so that they more closely resembled Penaeus monodon hemolymph. Specifically, osmolarity was 640 to 690 mOsm kg ${ }^{-1}$, and glucose, $\mathrm{Na}^{+}, \mathrm{Cl}^{-}, \mathrm{Ca}^{++}$, and $\mathrm{Mg}^{++}$ concentrations were $6,352,320,13$, and $6 \mathrm{mM}$ respectively. All media with osmolarity at $690 \mathrm{mOsm} \mathrm{kg}^{-1}$ were supplemented with $20 \%$ fetal bovine serum. NCTC, $2 \times$ L15, and TNM-FH were evaluated for their suitability for growth of lymphoid cells by counting the number of living cells (no. $\mathrm{cm}^{-2} \pm \mathrm{SD}$ ) during a $7 \mathrm{~d}$ observation period. These trials were replicated 5 times.

Effect of osmolarity of culture media (L15) on living shrimp cells. Based on the results of the preference tests described above, L15 was selected for the subsequent parts of this study. Double-strength L15 media with different osmolarities (measured by Micro-Osmometer 3MD Plus [ADVANCED] at 850, 690, 530, 450, and $300 \mathrm{mOsm} \mathrm{kg}{ }^{-1}$, all $\pm 5 \mathrm{mOsm} \mathrm{kg} \mathrm{kg}^{-1}$ ) were prepared as was a single-strength L15 medium $(480 \pm 5 \mathrm{mOsm}$ $\mathrm{kg}^{-1}$ ) based on the formula of Hsu et al. (1995). As before, all the prepared media were tested for their suitability for shrimp lymphoid cells by counting the number of live shrimp cells (no. $\mathrm{cm}^{-2} \pm \mathrm{SD}$ ) during a $14 \mathrm{~d}$ observation period (5 replications)

In vitro propagation of WSSV. Preparation and use of WSSV inoculum: The WSSV inoculum was extracted from the carapace of heavily infected shrimp (1-step PCR positive) Penaeus monodon as follows: the carapace $\left(0.1 \mathrm{~g} \mathrm{ml}^{-1}\right)$ was homogenized in serum-free $2 \times$ L15 medium and centrifuged at $3000 \mathrm{rpm}(1500 \times \mathrm{g})$ for $10 \mathrm{~min}$. The supernatant was filtered through a $0.45 \mu \mathrm{m}$ filter and used as inoculum. This inoculum was also diluted 1:10 and 1:100 with serum-free $2 \times$ L15 medium. The inoculum and its 2 dilutions (500 $\mu 1)$ were used to inoculate confluent cell cultures from the lymphoid organ. After $1 \mathrm{~h}$ for adsorption, the viral solution was removed and the cells were incubated at $28^{\circ} \mathrm{C}$ in completely fresh $2 \times \mathrm{L} 15$ (pH 7.4) medium with the osmolarity level at $530 \mathrm{mOsm} \mathrm{kg} \mathrm{kg}^{-1}$. At this time, the morphology of the shrimp cells remained normal, and no apparent cytotoxic effects were observed. Some confluent cell cultures that were not exposed to virus served as controls.

WSSV detection in the primary culture cells by in situ hybridization: In the present study, we used a modified version of an in situ hybridization method described by Lightner (1996). Briefly, infected cells cultured on coverslips were fixed in cold methanol. This was followed by rehydration and post-fixation in cold $0.4 \%$ formaldehyde. A digoxigenin (DIG)-labeled 
WSSV-specific probe was prepared as described previously (Lo et al. 1997a). The hybridization and staining procedures were as described by Lightner (1996). After staining, the cells were counterstained with $0.5 \%$ Bismarck brown for $1 \mathrm{~min}$ and this was followed by dehydration. The coverslips were then mounted inverted with Entellan mounting medium. Photomicrographs were taken using an Olympus Research Microscope Model AHBT3.

Ultrastructural observations by transmission electron microscopy (TEM): Inoculated (10x dilution) primary culture cells were harvested at 1,3 , and 5 d postinoculation in $25 \mathrm{~cm}^{2}$ flasks. Control cells were also harvested after $6 \mathrm{~d}$ of incubation. Harvested cells were centrifuged at $1000 \mathrm{rpm}(175 \times \mathrm{g})$ for $10 \mathrm{~min}$, and the resultant cell blocks were prefixed in $2.5 \%$ glutaraldehyde in $0.1 \mathrm{M}$ cold phosphate buffer solution ( $\mathrm{pH} 7.2$ ) for $3 \mathrm{~h}$ at $4^{\circ} \mathrm{C}$. They were postfixed in $1 \% \mathrm{OsO}_{4}$ for $2 \mathrm{~h}$ at $4^{\circ} \mathrm{C}$. The fixed samples were then dehydrated in an alcohol gradient series (from $70 \%$ to absolute alcohol) and embedded in Spurr epon. Ultrathin sections were cut on a Reichert OMU ultramicrotome and stained with uranyl acetate and lead citrate. Transmission electron micrographs were made with a Hitachi $\mathrm{H}-600$ electron microscope at $100 \mathrm{kV}$.

\section{RESULTS}

\section{Medium selection for primary cell cultures}

Table 1 shows the number of lymphoid cells counted during the $7 \mathrm{~d}$ evaluation period. One day after explantation, there were twice as many living cells in $2 \times$ L15 medium as in TMN-FH medium and 3 times as many as in NCTC medium. Even at $7 \mathrm{~d}$ after explantation, about half of the living lymphoid cells remained viable in $\mathrm{L} 15$ medium, but the cells in NCTC and TMN-FH media became detached from the bottom of flask. Thus, L15 medium was evidently preferred by the lymphoid cells.
Table 1. Effect of 3 synthetic media (all supplemented with $20 \%$ FBS) with osmolarity at $690 \mathrm{mOsm} \mathrm{kg} \mathrm{kg}^{-1}$ on the number of migrating lymphoid cells (no. $\mathrm{cm}^{-2} \pm \mathrm{SD}$ ) during a $7 \mathrm{~d}$ observation period using 5 independent replications. NCTC: NCTC-135 medium; 2x L.15: Leibovitz's L15 medium; TNMFH: Modified Grace Insect medium

\begin{tabular}{|cccc|}
\hline $\begin{array}{l}\text { Culture } \\
\text { days }\end{array}$ & NCTC & $\begin{array}{c}\text { Media } \\
2 \times \text { L15 }\end{array}$ & TNM-FH \\
\hline 1 & $360 \pm 121$ & $1176 \pm 142$ & $657 \pm 124$ \\
2 & $213 \pm 101$ & $1455 \pm 254$ & $174 \pm 64$ \\
3 & $27 \pm 14$ & $1125 \pm 147$ & $46 \pm 25$ \\
4 & $28 \pm 7$ & $1092 \pm 214$ & $36 \pm 25$ \\
7 & $0 \pm 0$ & $588 \pm 143$ & $0 \pm 0$ \\
\hline
\end{tabular}

while the number of cells in the other media declined. On the third and fourth days after seeding, the number of cells in the 690,530 , and $450 \mathrm{mOsm} \mathrm{kg} \mathrm{kg}^{-1}$ media declined. By the seventh day, the number of cells in all the media except the $480 \mathrm{mOsm} \mathrm{kg}^{-1}$ medium had dropped, and in the media with the highest and lowest osmolarity (i.e. 850 and 300 mOsm $\mathrm{kg}^{-1}$ ) almost all of the cells had detached from the flask bottom. Fourteen days after seeding, the number of cells in the 690 and $530 \mathrm{mOsm} \mathrm{kg} \mathrm{k}^{-1}$ media recovered to levels that were comparable to initial cell densities of the first day, while cell numbers in the 450 and $480 \mathrm{mOsm} \mathrm{kg}^{-1}$ media fell to about one half and one third, respectively, of the initial levels. No viable cells remained in the 850 and 300 mOsm kg-1 media. These results suggested that either 690 or $530 \mathrm{mOsm} \mathrm{kg}^{-1}$ would be adequate for culture media, and we selected $530 \mathrm{mOsm} \mathrm{kg}^{-1}$ for the subsequent parts of this study.

\section{Types of lymphoid cells in primary cell culture}

Migration of lymphoid cells from the seeded tissue fragments was first observed at $6 \mathrm{~h}$ after explantation, and the cells were confluent at $24 \mathrm{~h}$. Three different

\section{Effect of osmolarity in L15 medium}

Osmolarity results are shown in Table 2. On Day 1, except for the highest and lowest osmolarity groups, there was no significant difference in the number of living lymphoid cells (around 2500 cells $\mathrm{cm}^{-2}$ ). On the second day, the cells in the 690 and 530 mOsm $\mathrm{kg}^{-1}$ media continued to migrate,
Table 2. Effect of osmolarity of L15 culture media ( $1 \times$ and $2 \times \mathrm{L} 15 ; \mathrm{mOsm} \mathrm{kg}^{-1}$ given in parentheses) on the number of viable shrimp cells (no. $\mathrm{cm}^{-2} \pm \mathrm{SD}$ ) during a $14 \mathrm{~d}$ observation period

\begin{tabular}{|ccccccc|}
\hline $\begin{array}{c}\text { Culture } \\
\text { days }\end{array}$ & $\begin{array}{c}\text { M L15 } \\
(850)\end{array}$ & $\begin{array}{c}2 \times \mathrm{L} 15 \\
(690)\end{array}$ & $\begin{array}{c}2 \times \mathrm{L} 15 \\
(530)\end{array}$ & $\begin{array}{c}2 \times \mathrm{L} 15 \\
(450)\end{array}$ & $\begin{array}{c}1 \times \mathrm{L} 15 \\
(480)\end{array}$ & $\begin{array}{c}2 \times \mathrm{L} 15 \\
(300)\end{array}$ \\
\hline 1 & $504 \pm 80$ & $2433 \pm 232$ & $2849 \pm 257$ & $2916 \pm 352$ & $2390 \pm 347$ & $55 \pm 23$ \\
2 & $636 \pm 200$ & $3108 \pm 371$ & $3411 \pm 478$ & $2522 \pm 314$ & $2009 \pm 411$ & $62 \pm 25$ \\
3 & $856 \pm 120$ & $2664 \pm 271$ & $2924 \pm 371$ & $1974 \pm 351$ & $2070 \pm 142$ & $38 \pm 21$ \\
4 & $320 \pm 136$ & $2458 \pm 324$ & $2291 \pm 274$ & $1544 \pm 414$ & $1909 \pm 324$ & $29 \pm 18$ \\
7 & $60 \pm 15$ & $1652 \pm 143$ & $1983 \pm 158$ & $1086 \pm 443$ & $2073 \pm 243$ & $0 \pm 0$ \\
14 & $0 \pm 0$ & $2114 \pm 165$ & $2313 \pm 475$ & $1490 \pm 355$ & $895 \pm 165$ & $0 \pm 0$ \\
\hline
\end{tabular}


cell types were identified: fibroblast-like cells, squamous cells, and round cells (Fig. 1A). The fibroblast-like cells were elongated in shape and had more than 2 cytoplasmic processes. Migration proceeded rapidly and the cells finally formed a network around the seeded tissue explant. Squamous cells were first observed $24 \mathrm{~h}$ after seeding. There were far fewer of them than fibroblast-like cells and they were distributed only in the immediate vicinity of the explant. In most cases, they were covered by fibroblastlike cells by $48 \mathrm{~h}$. Round cells were the smallest and rarest of the 3 cell types. They had between 0 and 3 short cytoplasmic processes and were sparsely distributed around the explant.

\section{In vitro propagation of WSSV and in situ hybridization}

Cytopathic effects (CPE) on lymphoid cells were first observed 2 d post-inoculation with undiluted WSSV filtrate. The control lymphoid cells after $4 \mathrm{~d}$ seeding and the infected cells at $3 \mathrm{~d}$ post-inoculation are showed in Fig. 1B,C, respectively. The affected cells initially exhibited shrinkage, and small fragments of cell debris were found between cells (Fig. 1C). As the infection progressed, CPE became more apparent: most cells became detached from the bottom of the flask, cell debris increased and cells eventually lysed at $6 \mathrm{~d}$ post-inoculation.

The cultured lymphoid cells were further confirmed to be permissive to WSSV by using in situ hybridization with a WSSV-specific probe. Two d after inoculation with undiluted inoculum, WSSVpositive signals were observed in $90 \%$ of the cells. With diluted inocula (i.e. $10 \times$ and $100 x$ ) infection rates were less than $10 \%$. By $3 \mathrm{~d}$ post-inoculation the infection rate of the undiluted group reached $100 \%$, while the infection rates in the $10 \times$ and $100 \times$ dilution groups were about $65 \%$ and less than $10 \%$, respectively (Figs. 2 \& 3). No WSSV-positive signals were observed in cells of the control group.

By ultrastructure, 6 different types of cell could be morphologically distinguished in the primary lymphoid culture.
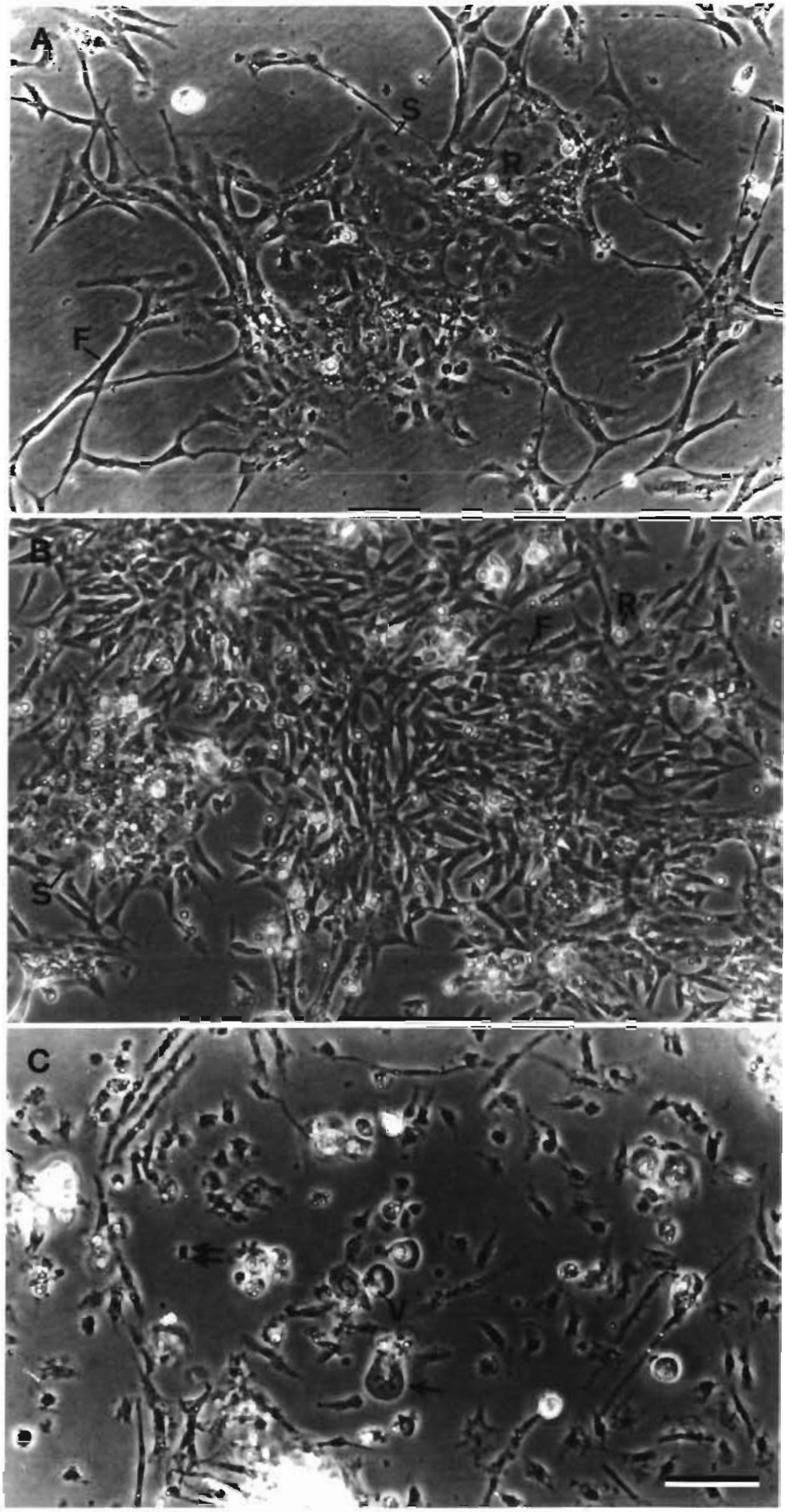

Fig. 1. The morphology of cultured lymphoid cells of Penaeus monodon. (A, B) Uninfected cells 1 and $4 \mathrm{~d}$ after seeding, respectively, where 3 types of lymphoid cell can be seen: fibroblast-like cells $(F)$, squamous cells (S) and round cells (R). (C) WSSV infected lymphoid cells 3 d post-inoculation; cytopathic effects can be seen: the nuclei of infected cells were either hypertrophied (arrow) or shrunken (double arrows). Large vacuoles (V) were frequently observed in infected cells and cell debris was found between infected cells. Scale bar $=40 \mu \mathrm{m}$ 

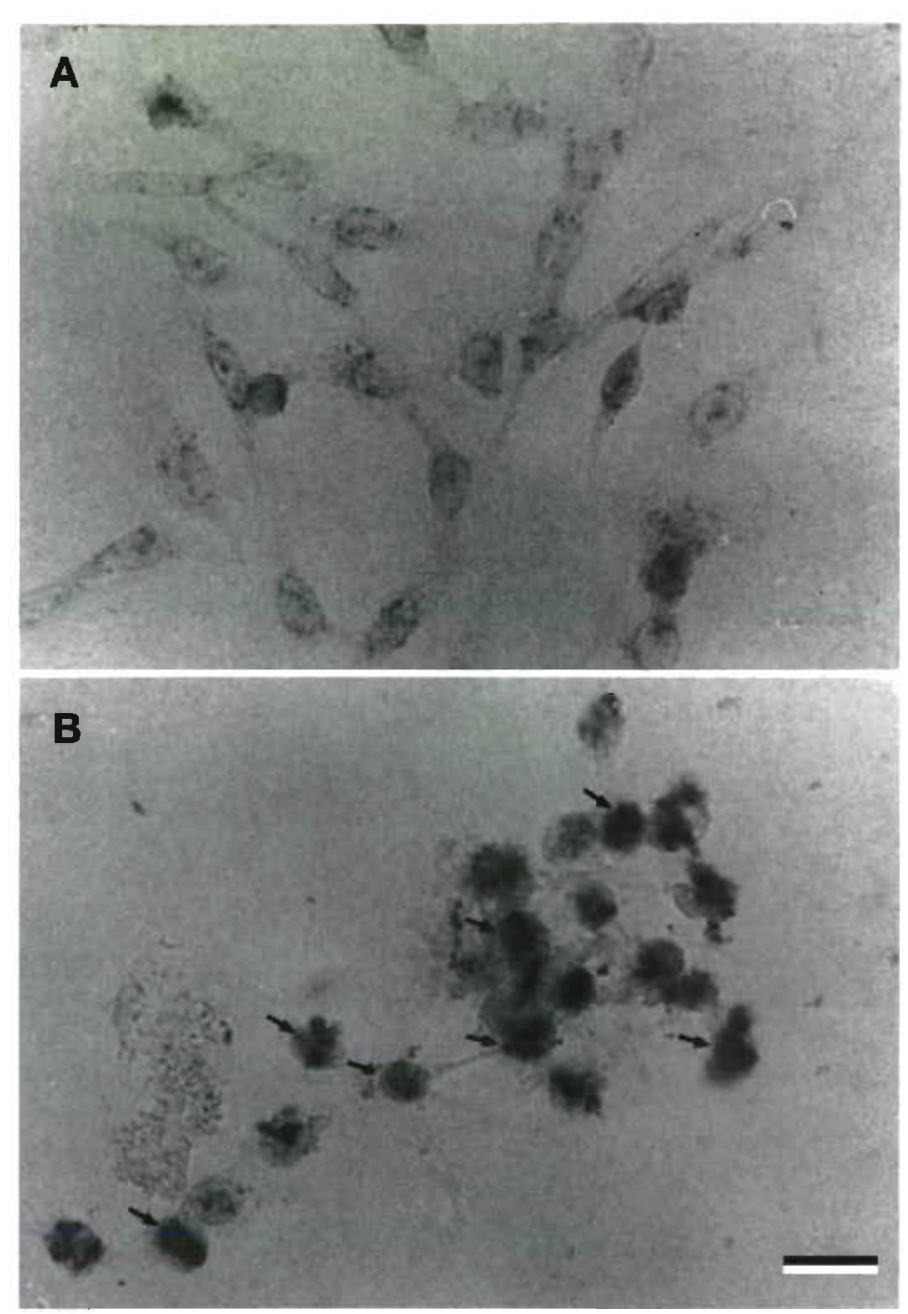

Fig. 2. WSSV detection in primary lymphoid cells by in situ hybridization showing (A) WSSV-negative reaction in uninfected cells and (B) WSSV-positive signals (arrows) in cells at $3 \mathrm{~d}$ postinfection with diluted $10 \times$ WSSV inoculum. Scale bar $=30 \mu \mathrm{m}$

These are described in the following paragraphs:

(1) Fibroblast-like cells (F cells, Fig. 4A) were surrounded by and in close contact with an abundance of collagen-like fibers. They were elongated, interconnected and_similarly oriented so that sheet-like assemblages were formed in the flask. The nuclei were elongated parallel to the long axis of the cell, and contained either 1 or 2 nucleoli. Several relatively large, elongate mitochondria were usually observed in the cytoplasm. The cytoplasm also had well-developed, endoplasmic reticular tubules (rER and $s E R$ ) and contained a large vacuole close to the nucleus. The vacuoles and intercellular spaces were filled with collagen-like fibers.

(2) Phagocytes (Ph cells, Fig. 4B) were highly phagocytic cells usually surrounded by a cluster of collagenlike fibers in an amorphous matrix. Their cytoplasm contained many phagosomes, dense bodies and het-

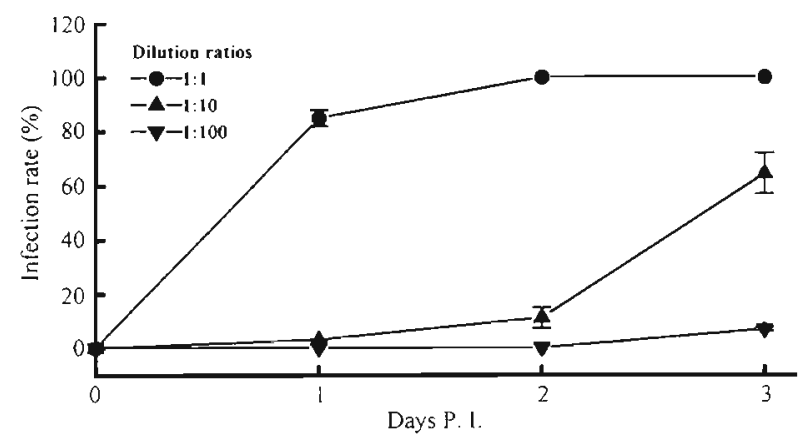

Fig. 3. Infection rates of cultured lymphoid cells with 3 concentrations of inoculum. Infection rates were defined as (number of infected cells/total observed cells) $\times 100 \%$ and based on in situ hybridization data

erogeneous vesicles, and numerous cell digitations were observed at the cell margin. The nuclei were of various shapes and had either 1 or no nucleolus. They connected with each other by cytoplasmic processes and formed a network. The intercellular spaces were commonly filled with fibers.

(3) Granulocytes (Gr cells, Fig. 4C) were more or less round in shape. Filopodia and/or other irregular processes were seen in the plasma membrane. The nucleus was generally centrally located and had a single nucleolus. The cytoplasm contained electron-dense granules of various sizes (from 0.15 to $0.58 \mu \mathrm{m}$ in diameter) and a few heterogeneous vesicles or phagosomes

(4) Reticular cells (Re cells, Fig. 4D) were highly polymorphic and extruded many thick and extremely ramified cytoplasmic processes to form a complex network. The cytoplasmic processes of different Re cells frequently made contact. In addition to these long processes, there were also numerous deep indentations at the cell periphery. The lobed nucleus contained a conspicuous nucleolus. The endoplasmic reticular system was not very conspicuous and each cell had only a few mitochondria (Fig. 4D).

(5) Cells with a pycnotic nucleus (Pn cells, Flegel et al. 1992) were of various sizes and their nuclei were extremely electron-dense. We distinguished 2 subtypes: large Pn cells (Fig. 4E1) and small Pn cells (Fig. 4E2). The nuclei of the large PN cells were generally round or oval in shape, about $4.7 \mu \mathrm{m}$ in diameter, and centrally located. The round and/or oval-shaped electron-dense central part of the nucleus, which accounted for about $90 \%$ of its total volume, was surrounded by a ring-like electron-lucent nucleoplasm. The plasma membrane had a few cytoplasmic processes and the cytoplasm contained 1 or 2 phagosomes. The small Pn cells contained an eccentrically located electron-dense nucleus, about $1.7 \mu \mathrm{m}$ in diameter, and a conspicuous rough endoplasmic reticulum in the cytoplasm. 


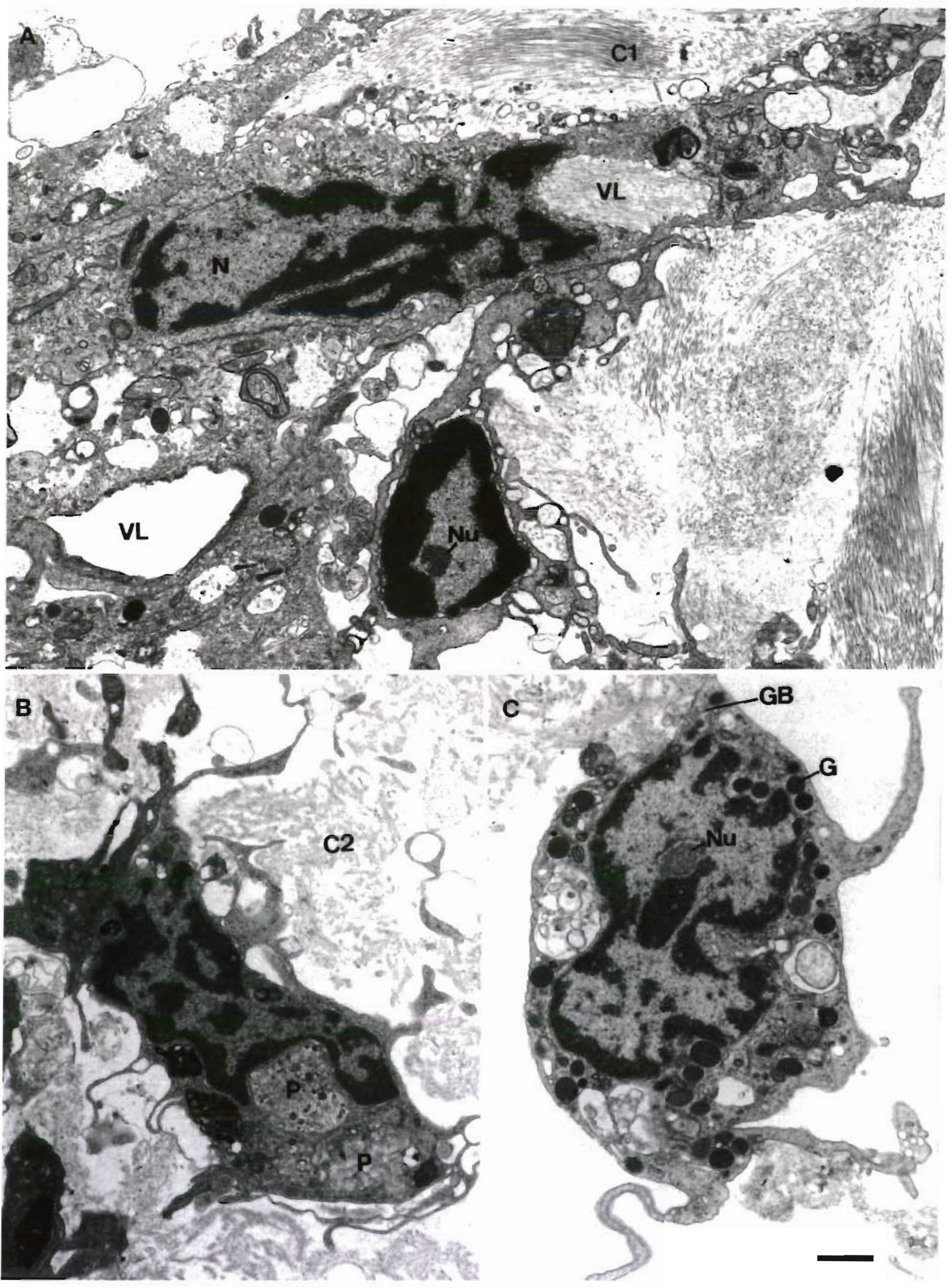




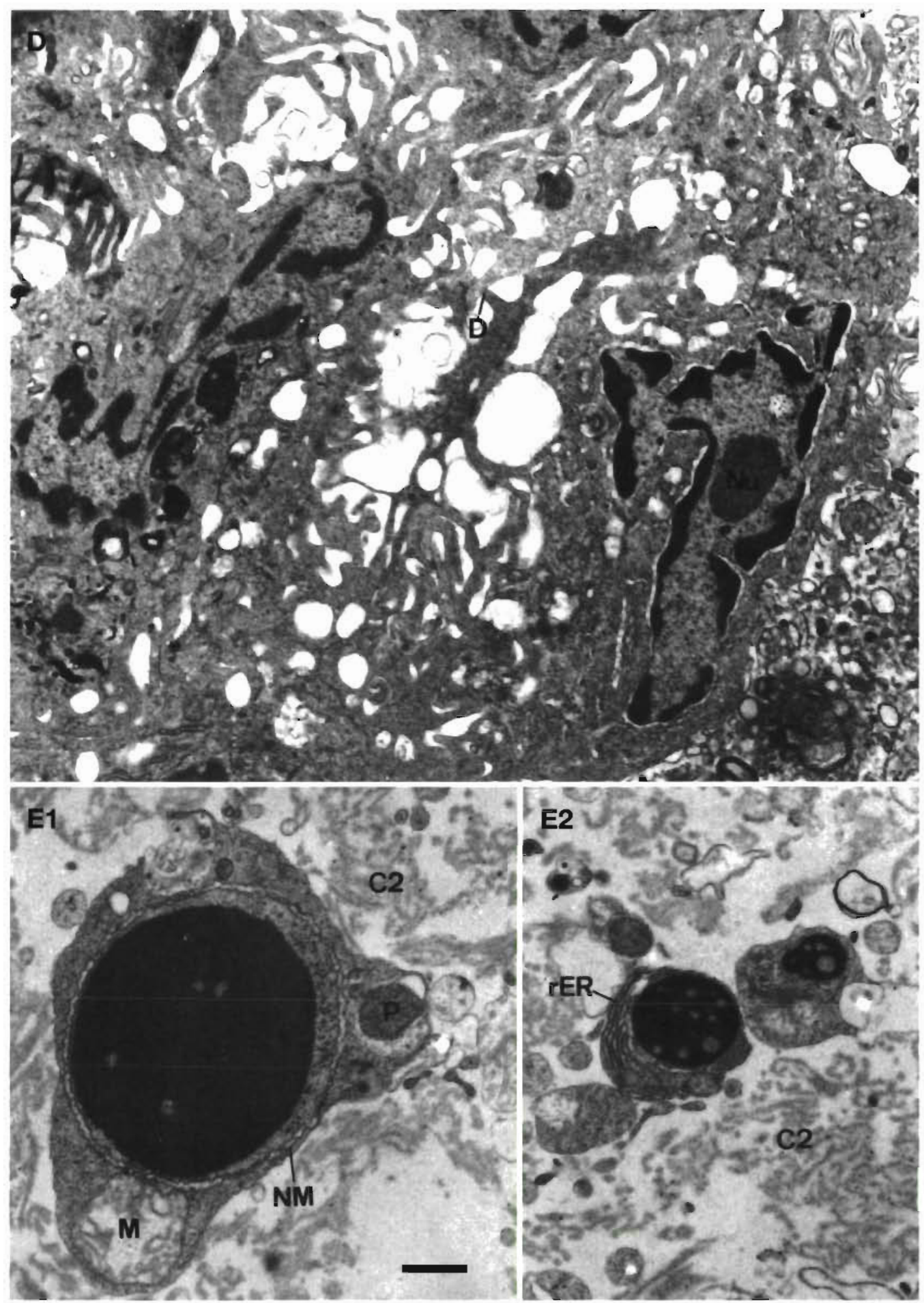

Fig. 4 (facing page, above, and next page). Electron micrographs of the 6 types of cultured lymphoid cells of Penaeus monodon, showing (A) Fibroblast-like cells, (B) phagocyte, (C) granulocyte, (D) reticular cells, (E1, E2) large and small cells, respectively, with pycnotic nuclei and (F) adipose cells. C1: collagen-like fibers; C2: collagen-like fibers with amorphic matrix; D: desmosomelike junction; G: granule; GB: Golgi body; L: lipid droplet; M: mitochondria; N: nucleus; NM: nuclear membrane; Nu: nucleolus; P: phagosome; Ph: phagocyte; rER: rough endoplasmic reticulum; sER; smooth endoplasmic reticulum; VL: large vacuole in fibroblast-like cell. Scale bar $=1 \mu \mathrm{m}$ 


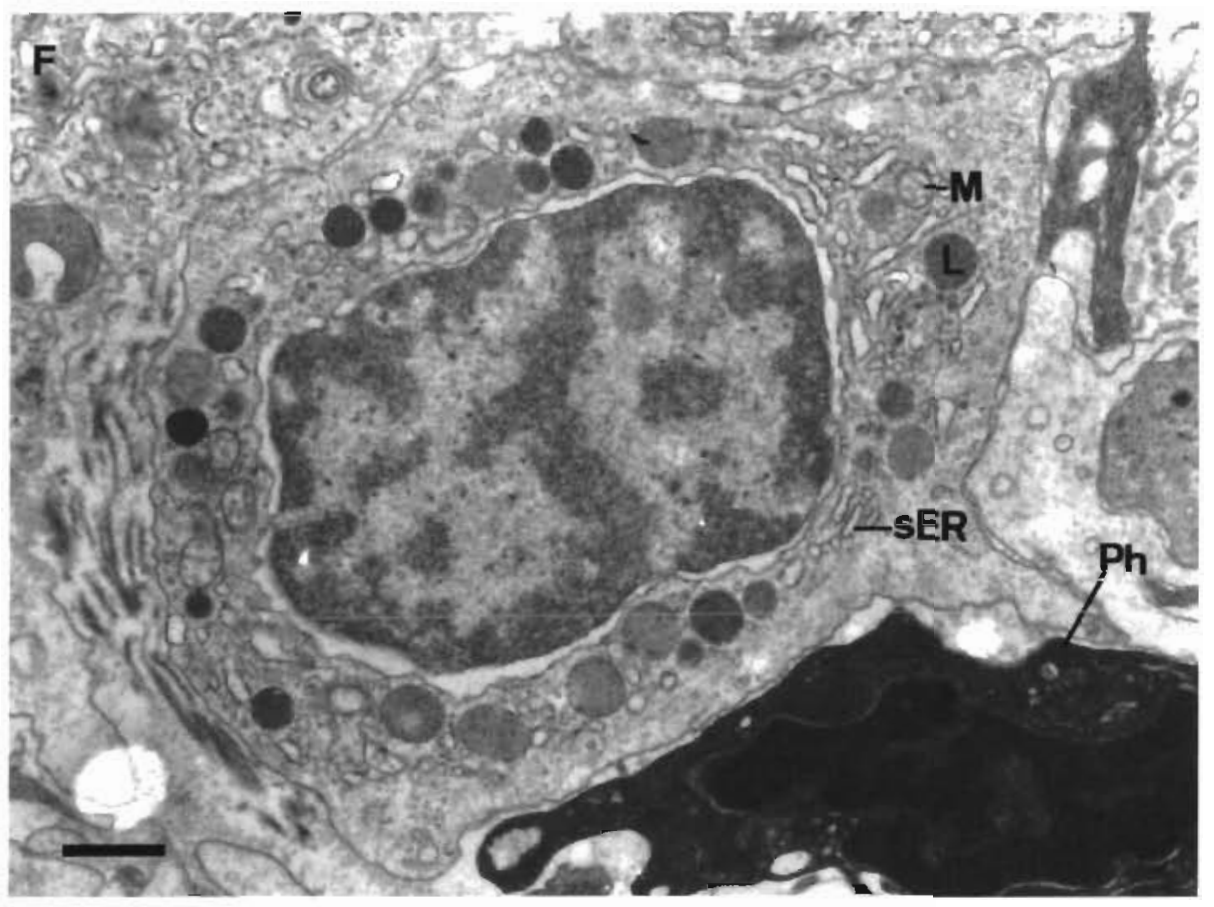

Fig. 4 (continued)

Table 3. WSSV infection prevalence of 6 different cell types in 250 observed cultured lymphoid cells at $3 \mathrm{~d}$ post-inoculation

\begin{tabular}{|c|c|c|c|c|c|c|}
\hline \multirow{2}{*}{ Prevalence } & \multirow[b]{2}{*}{$\begin{array}{l}\text { Fibroblast- } \\
\text { like cell }\end{array}$} & \multirow[b]{2}{*}{ Phagocyte } & \multicolumn{2}{|c|}{ Cell type } & \multirow[b]{2}{*}{$\begin{array}{c}\text { Denso- } \\
\text { nuclear cell }\end{array}$} & \multirow[b]{2}{*}{ Adipocyte } \\
\hline & & & Granulocyte & $\begin{array}{l}\text { Reticular } \\
\text { cell }\end{array}$ & & \\
\hline $\begin{array}{l}\text { Infected cells/total } \\
\text { observed cells }(\%)\end{array}$ & $\begin{array}{l}2 / 250 \\
(0.8)\end{array}$ & $\begin{array}{c}0 / 250 \\
(0.0)\end{array}$ & $\begin{array}{l}5 / 250 \\
(2.0)\end{array}$ & $\begin{array}{l}2 / 250 \\
(0.8)\end{array}$ & $\begin{array}{c}0 / 250 \\
(0.0)\end{array}$ & $\begin{array}{c}3 / 250 \\
(1.2)\end{array}$ \\
\hline $\begin{array}{l}\text { Infected cells' } \\
\text { cell-type total }(\%)\end{array}$ & $\begin{array}{c}2 / 11 \\
(18.2)\end{array}$ & $\begin{array}{l}0 / 83 \\
(0.0)\end{array}$ & $\begin{array}{l}5 / 89 \\
(5.6)\end{array}$ & $\begin{array}{l}2 / 25 \\
(8.0)\end{array}$ & $\begin{array}{l}0 / 14 \\
(0.0)\end{array}$ & $\begin{array}{l}3 / 28 \\
(10.7)\end{array}$ \\
\hline
\end{tabular}

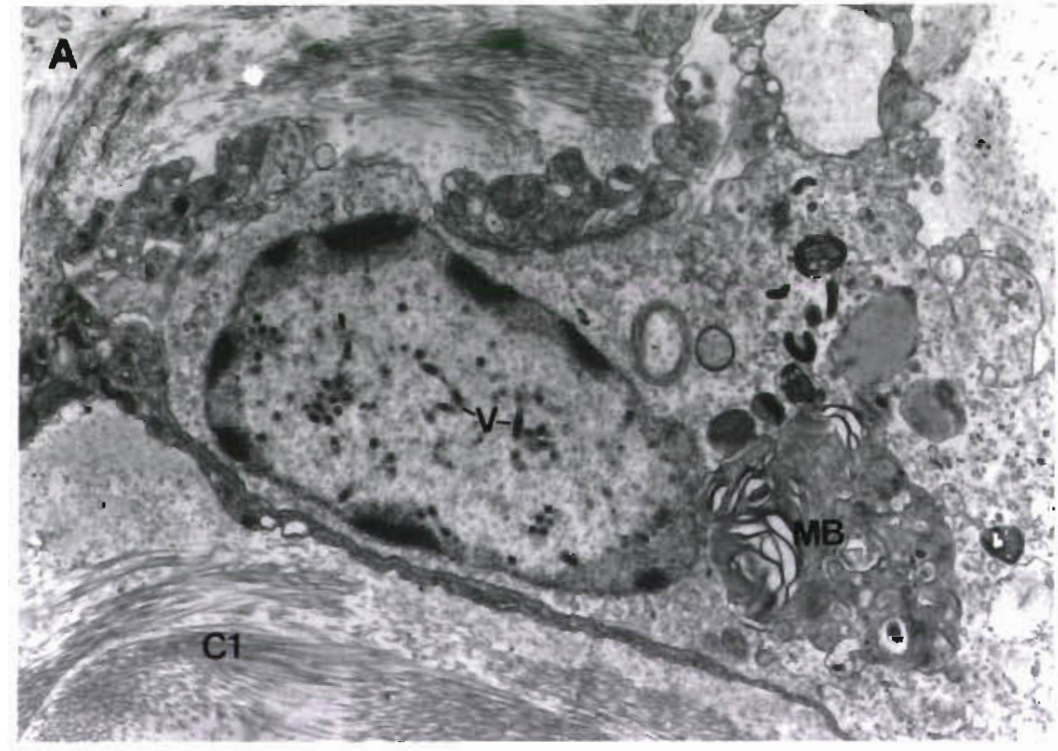

Fig. 5. Electron micrographs of WSSV. infected cultured lymphoid cells of Penaeus monodon at $3 \mathrm{~d}$ post-inoculation. (A) Fibroblast-like cell, (B) granulocyte, (C) reticular cell, and $(D)$ adipose cells. C1: collagen-like fibers; F: fibrillar mass; G: granule; L: lipid droplet; M: mitochondria; MB: multivesicular body; $V$ : virion. Scale bar $=1 \mu \mathrm{m}$ 


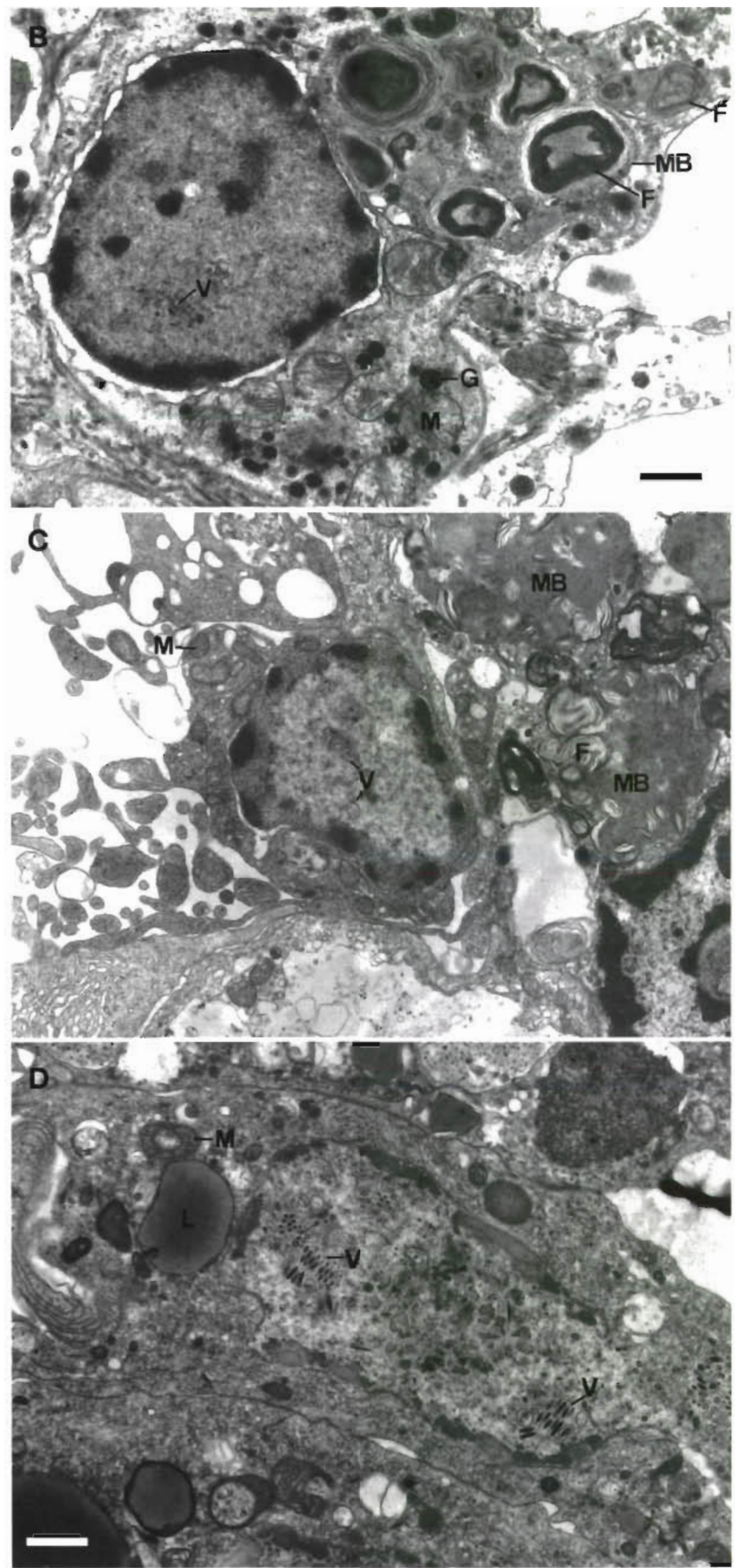

(6) Adipose cells (Ad cells, Fig. 4F) were electron-lucent, and had few cytoplasmic processes. Their cytoplasm contained many lipid droplets, secondary lysosomes and smooth endoplasmic reticulum.

Based on electron microscopic observation of these uninfected, control primary cultured lymphoid cells at $4 \mathrm{~d}$ after initial seeding, Gr cells accounted for about $35.6 \%$ of the population. Next most common were $\mathrm{Ph}$ cells (33.2\%), followed by Ad cells (11.2\%), Re cells $(10.0 \%)$, Pn cells $(5.6 \%)$, and F cells $(4.4 \%)$. The electron micrographs of the infected cultured lymphoid cells at $3 \mathrm{~d}$ post-inoculation were examined and the WSSV infection percentage was also determined (Table 3). Except for Ph cells and Pn cells, all the other cells were susceptible to WSSV infection (Figs. 5A-D $\& 6 \mathrm{~A}-\mathrm{C}$ ). Infected $\mathrm{Gr}$ cells accounted for $2.0 \%$ of 250 observed cells. Next were infected Ad cells (1.2\%), followed by $F$ cells $(0.8 \%)$ and Re cells $(0.8 \%)$. On the other hand, comparison of cell type infection prevalence showed that $18 \%$ of F cells (2/11) were infected followed by $11 \%$ Ad cells, $8 \%$ of Re cells and $6 \%$ of Gr cells (Table 3). During the course of infection these susceptible cells all exhibited similar cytopathogenesis.

Early cytopathic changes associated with WSSV infection included increasing hypertrophy of the nucleus and margination and diminution of nuclear chromatin. The hypertrophic nuclei of WSSV-infected cells consisted of 2 distinct areas: a marginal layer made up of electron-dense chromatin with several spots of heterochromatin, and a central, homogenous, electron-lucent matrix area with several clusters of developing virions (Fig. 6A,B). This central area was approximately round in shape, and its diameter depended on the progress of infection. In heavily infected cells (i.e. those full of mature virions), the marginal layer became very faint and often could not be seen by TEM (Fig. 6C). The infected cells also showed enlarged perinuclear cisternae and multivesicular bodies (Fig, 6A,B), and, especially in heavily infected cells, degenerate organelles could be seen in 


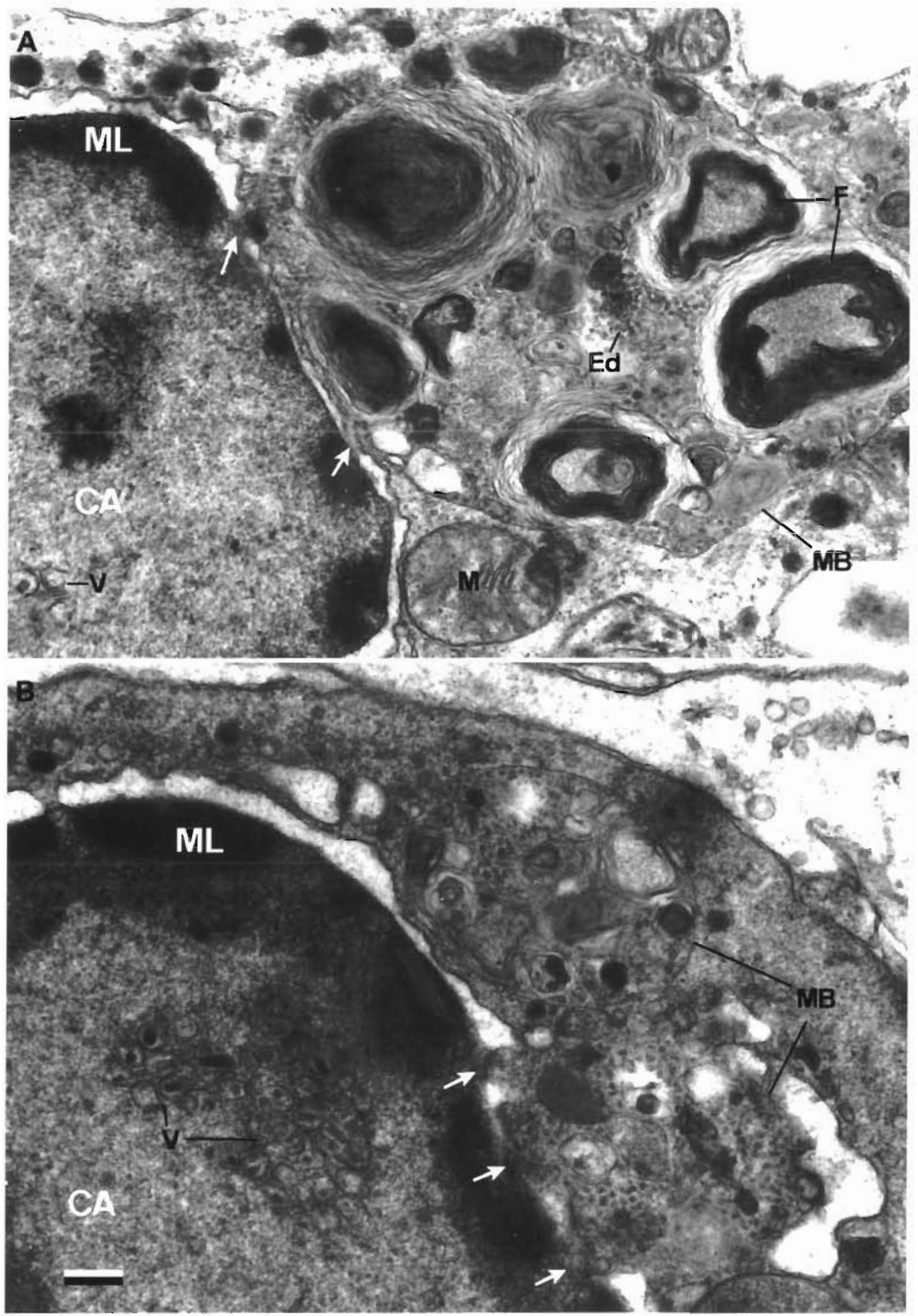

the cytoplasm. No obvious virogenic stroma appeared in the nuclei of infected cells. Fibrillar masses were not seen in the nuclei, but in the cytoplasm multivesicular bodies containing 1 to 6 fibrillar masses were seen. In profile, they appeared as spiral coils. These multivesicular bodies also contained many electron-dense particles $30 \mathrm{~nm}$ in diameter (Fig. 6A,B). The membrane of the multivesicular bodies fused with the outer nuclear membrane and digital processes from them seemed to extend directly to the nuclear pore (Fig. 6B). The central nuclear areas of infected cells were filled with many empty nucleocapsid shells (capsids; Figs. 6B \& $7 \mathrm{~A}$ ). Most of these empty capsids were surrounded loosely with an envelope, and both the shell and enve- 


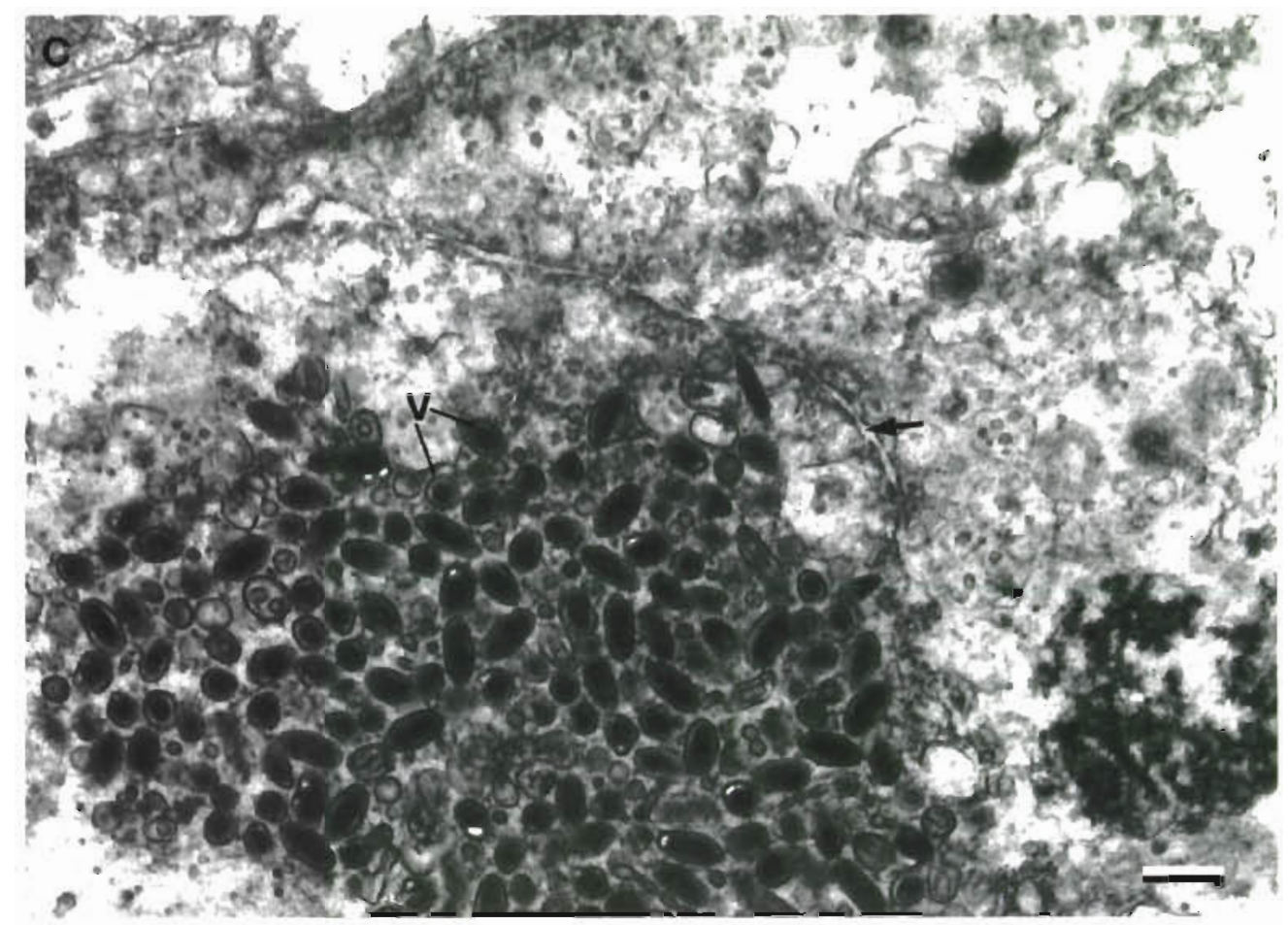

Fig. 6. WSSV-infected lymphoid cells. (A) A higher magnification of Fig. 5B showing that the hypertrophic nucleus consists of 2 distinct areas, the marginal layer (ML) and central area (CA). The central area contains several clusters of developing virions (V). A distinct multivesicular body (MB) contains at least 7 fibrillar masses (F) and many electron-dense particles (Ed). This multivesicular body is in close contact with the hypertrophic nucleus and its membrane has fused with the nuclear pores (arrows). Mitochondria (M) are also present. (B) Two multivesicular bodies (MB) in the cytoplasm of an infected cell. An intact multivesicular body is located at the upper-right side of the infected cell, while the contents of the multivesicular body on the lower-right have already gained access to the interior of the nucleus through several nuclear pores (arrows); only a few fibrillar masses remain in the body. (C) A heavily infected cell, i.e. a cell with many mature virions (V) in its nucleus. The nuclear envelope can still be distinguished (arrow), but the chromatin and the other organelles including the multivesicular bodies can no longer be discerned. The infected cells in (A) and (B) were harvested at $3 \mathrm{~d}$ post-inoculation and the infected cell in (C) was prepared at $5 \mathrm{~d}$ post-inoculation. Scale bar $=300 \mathrm{~nm}$

lope were open at the same end. In Fig. $7 \mathrm{~A}$, electrondense threads can be seen extending directly through the open ends of 2 of these incompletely enveloped capsids. By contrast, in some other infected cells (Fig. 7B), unenveloped electron-dense nucleocapsids were arranged regularly in the infected nuclei.

\section{DISCUSSION}

Previous efforts to establish shrimp cell lines permissive to WSSV or other economically damaging viral shrimp pathogens have tested various media, and other factors suitable for the growth of shrimp cells (Chen et al. 1986, Chen \& Kou 1989, Nadala et al. 1993, Hsu et al. 1995, Tapay et al. 1995). Favorable results have generally been obtained using the basic medium L15 at around $\mathrm{pH} 7.5$. In the present paper, L15 again produced good results (Table 1), although the optimal osmolarity range was quite different from that previously reported. For example, Hsu et al. (1995) recommended $1 \times \mathrm{L} 15$ at 470 to $500 \mathrm{mOsm} \mathrm{kg}^{-1}$, while Chen \& Kou (1989) and Tapay et al. (1995) recommended $2 \times$ L15 at 750 to $770 \mathrm{mOsm} \mathrm{kg}^{-1}$. By contrast, our data suggested that $2 \times \mathrm{L} 15$ at 530 to $690 \mathrm{mOsm} \mathrm{kg}^{-1}$ was most suitable (Table 2). As Penaeus monodon is a very strong osmoregulator (Cheng \& Liao 1986), the fact that its lymphoid organ cells remain viable under quite a wide range of osmolar conditions (from at least 470 to $770 \mathrm{mOsm} \mathrm{kg}{ }^{-1}$ ) should not be surprising. Indeed, throughout $14 \mathrm{~d}$ of culture the numbers of live cells at 530 and $690 \mathrm{mOsm} \mathrm{kg}^{-1}$ were not very different (Table 2).

The F cells (Fig. 4A) and Re cells (Fig. 4D) that were observed in the seeded lymphoid tissue appear to correspond to spheroid cells and tubule cells, respectively, 


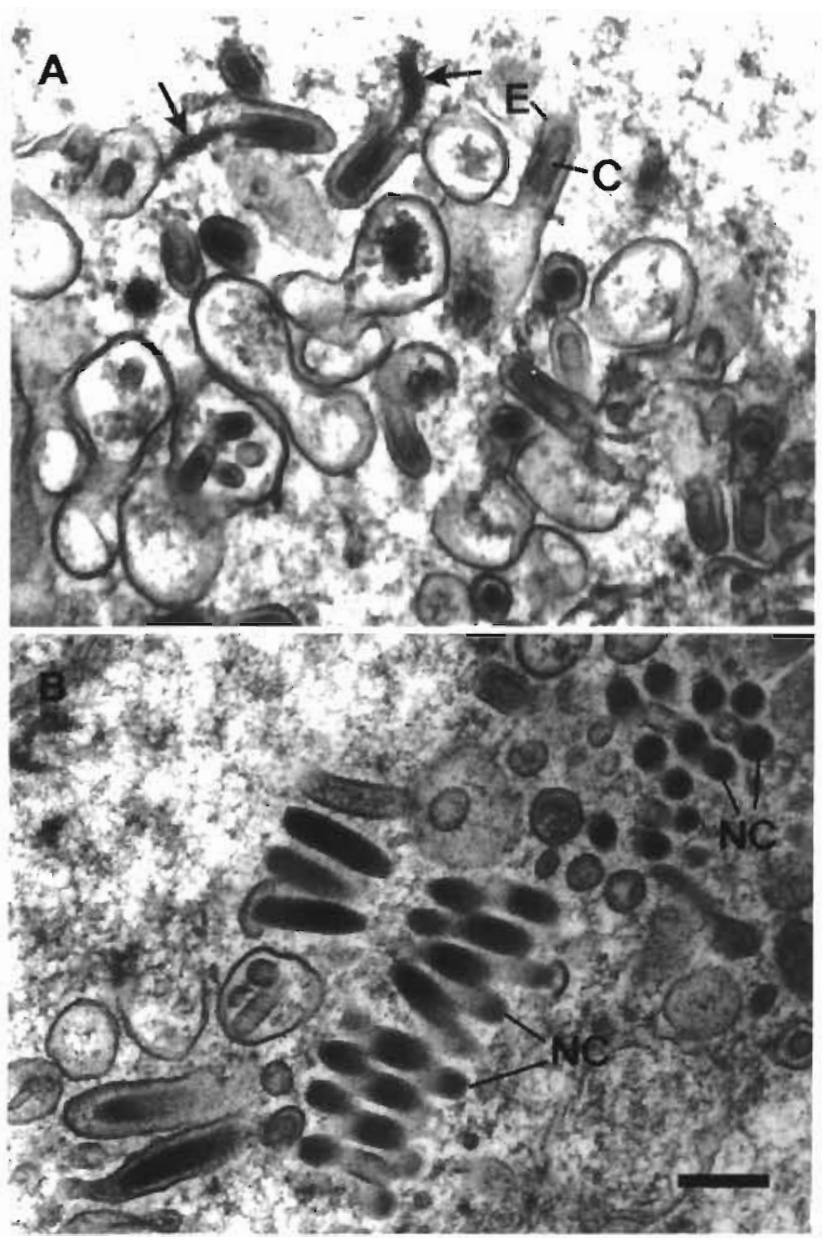

Fig. 7. Morphogenesis of WSSV in cultured lymphoid cells showing 2 ways of WSSV assembly. (A) Incomplete capsids (C) and envelopes (E) which loosely surround them are assembled first, while the electron-dense core (arrows) is inserted later. (B) Unenveloped electron-dense nucleocapsids (NC) were arranged regularly in the infected nucleus and subsequently surrounded with an envelope. Scale bar $=200 \mathrm{~nm}$

in the lymphoid organ itself (Flegel et al. 1992). Further evidence for this correspondence is that in vitro the reticular cells connected with each other by ramified cytoplasmic processes to form a fenestrated sheet (Fig. 4D) that is very similar in physical structure to cells that line lymphoid organ tubules in vivo (authors' unpubl. data). Since Pn cells (Fig. 4E1, E2) resembled both free and phagocytized degenerated cells in the lymphoid organ (authors' unpubl, data), they might be degenerated cells. Although the large PN cells contained phagosomes, it is possible that both the large and smali PN cells could in fact be portions of degenerated phagocytic cells. (Apoptotic bodies were found in both uninfected and WSSV-infected cells [data not shown].) Similarly, Gr cells with phagocytic vesicles containing small granules could correspond to the small granular hemocytes (SGH) described by Tsing \& Arcier (1989)

$F$ cells were the most WSSV susceptible cell type (Table 3, Figs. 4 \& 5A). However, the cytopathic effects manifested in all the susceptible cell types were similar. These included changes in the number of mature and developing WSSV virions in the central area of the nuclei, the ratio of the marginal area of the nucleus to its central area, the size and/or number of multivesicular bodies in the cytoplasm, and the extent to which the organelles in the cytoplasm degenerated (Fig. 5A-D). Except for the formation of the multivesicular bodies, all of these cytopathic changes are similar to those induced by the Oryctes virus (Huger \& Krieg 1991). The multivesicular bodies are membrane-bounded organelles in which the profiles of spirally coiled fibrillar masses (multilamellar membrane structures) can be seen in addition to other electron-dense particles (Fig. 6A,B). They are not specific to WSSVinfected cells: healthy phagocytes (Fig. 4B) also contain multivesicular bodies (heterophagosomes), which we interpret as being the engulfed residue from collapsed WSSV-infected cells. It is also possible that these multivesicular bodies are virogenic (Flegel et al. 1992) and resulted from another unidentified viral infection. Furthermore, although the electron-dense particles seen here (Fig. 6A,B) may be related to the presence of the virus, electron-dense particles per se are also not specific to WSSV-infected cells. Fig. 6B suggests that the boundary membrane of a multivesicular body ultimately fuses with the outer membrane of the nuclear envelope. Nevertheless, the real role of such multivesicular bodies will need to be elucidated in further studies.

Under the electron microscope, tail-like appendages similar to those of the Oryctes virus have been seen extending from WSSV virions in negatively stained WSSV preparations (Wang et al. 1995). Payne (1974) suggested that in Oryctes this tail-like appendage consists of nucleoprotein that is escaping from an internal component of the nucleocapsid, and that it is released when the viral envelope is removed. By contrast, the tail-like appendage in WSSV might result when an immature or developing virions are interrupted in the process of packing their electron-dense core (Durand et al. 1997). We interpret Fig. $7 \mathrm{~A}$ as showing virions which are in the process of being formed (as opposed to disintegrating). If this interpretation is correct, WSSV appears to be capable of 2 quite distinct methods of morphogenetic assembly. The first would be like the Oryctes virus (Huger \& Krieg 1991), in which WSSV would first assemble the virus envelope and nucleocapsid shell, and then fill them with the electron-dense nucleoprotein core (Fig. $7 \mathrm{~A}$ ), i.e. the procedure first described by Durand et al. (1997). The second assem- 
bly sequence would be more similar to that of a baculovirus (Adam \& McClintock 1991), in which the electron-dense nucleocapsids are assembled first and then enveloped (Fig. 7B).

In the late stages of infection, the hypertrophic nuclei are filled with an enormous number of closely packed virions. These virions may be arranged randomly (Fig. 6C) or they may be aligned in a para-crystalline pattern (Fig. 7B). Chou et al. (1995) reported that similarly configured groups of WSSV virions were released from the disrupted nucleus of epidermal cells and then readily budded from the cytoplasmic membrane. However, in the present study, there was no evidence of budding either from the nuclear envelope or from the cytoplasmic membrane. Possibly this was because of the different cell types studied (lymphoid as opposed to epidermal). Other differences between these 2 types of cell have already been documented. In a tissue tropism study (Lo et al. 1997), for instance, it has been shown that the lymphoid organ of shrimp is not heavily infected by WSSV. We infer from this that the virions in the nucleus of infected lymphoid cells are probably released only after cell lysis, an event which would occur in only a few cells.

In conclusion, we developed and successfully used a primary culture of lymphoid organ cells from Penaeus monodon to study WSSV morphogenesis. We found that WSSV assembly occurred only in the nuclei of infected cells and shared many morphogenetic similarities with both baculoviruses and Oryctes virus. The role of multivesicular bodies seen in the cytoplasm needs to be clarified.

Acknowledgements. This work was supported by the National Science Council under grant No. NSC 87-2311-B002-014-B20.

\section{LITERATURE CITED}

Adam JR, McClintock JT (1991) Baculoviridae: nuclear polyhedrosis viruses, Part 1 Nuclear polyhedrosis viruses of insects. In: Adams JR, Bonami JR (eds) Atlas of invertebrate viruses. CRC Press, Boca Raton, FL, p 87-204

Bedford CO (1981) Control of the rhinoceros beetle by baculovirus. In: Burges HD (ed) Microbial control of pests and plant diseases. Academic Press, New York, p 409-426

Chang PS, Lo CF, Wang YC, Kou GH (1996) Identification of white spot syndrome associated baculovirus (WSBV) target organs in shrimp, Penaeus monodon, by in situ hybridization. Dis Aquat Org 27:131-139

Chen SN, Kou GH (1989) Infection of cultured cells from the lymphoid organ of Penaeus monodon Fabricius by monodon-type baculovirus (MBV). J Fish Dis 12:73-76

Chen SN, Shi SC, Kou GH, Liao IC (1986) Cell culture from tissues of grass prawn, Penaeus monodon. Fish Pathol 21: $161-166$

Cheng JH, Liao IC (1986) The effect of salinity on the osmotic and ionic concentrations in the hemolymph of Penaeus monodon and Penaeus penicillatus. In: MacLean JK,
Dizon LB, Hosillos LV (eds) The First Asian Fisheries Forum. Asian Fisheries Society, Manila, p 633-636

Chou HY, Huang CY, Wang CH, Chiang HC, Lo CF (1995) Pathogenicity of a baculovirus infection causing white spot syndrome in cultured penaeid shrimp in Taiwan. Dis Aquat Org 23:165-173

Crawford A (1994) Nonoccluded baculoviruses. In: Webster RG, Franoff A (eds) Encyclopedia of virology. Academic Press, New York, p 133-139

Durand S, Lightner DV, Redman RM, Bonami JR (1997) Ultrastructure and morphogenesis of white spot syndrome baculovirus (WSSV). Dis Aquat Org 29:205-211

Flegel TW (1997) Major viral diseases of the black tiger prawn (Penaeus monodon) in Thailand. In: Inui Y (ed) New approaches to viral diseases of aquatic animals. NRIA International Workshop proceedings. National Research Institute of Aquaculture, Nansei, p 167-187

Flegel TW, Fegan DF, Kongsom S, Vuthikomudomkit $\mathrm{S}$, Sriurairatana S, Boonyaratpalin S, Chantanachookhin C, Vickers JE, Macdonald OD (1992) Occurrence, diagnosis and treatment of shrimp diseases in Thailand. In: Fulks W, Main KL (eds) Disease of cultured penaeid shrimp in Asia and the United States. The Oceanic Institute, Honolulu, HI, p 57-112

Hsu YL, Yang YH, Chen YC, Tung MC, Wu JL, Engelking $M H$, Leong JC (1995) Development of an in vitro subculture system for the oka organ (lymphoid tissue) of Penaeus monodon. Aquaculture 136:43-55

Huger AM, Krieg A (1991) Baculoviridae: nonoccluded baculoviruses. In: Adams JR, Bonami JR (eds) Atlas of invertebrate viruses. CRC Press, Boca Raton, FL, p 287-319

Kasornchandra J, Boonyaratpalin S (1998) Primary shrimp cell culture: Application for studying white spot syndrome virus (WSSV). In: Flegel TW (ed) Advances in shrimp biotechnology. National Center for Genetic Engineering and Biotechnology, Bangkok, p 273-276

Lightner DV (ed) (1996) A handbook of pathology and diagnostic procedures for diseases of penaeid shrimp. World Aquaculture Society, Baton Rouge, LA, Section 3.11

Lo $\mathrm{CF}_{1} \mathrm{Ho} \mathrm{CH}$, Peng SE, Chen $\mathrm{CH}, \mathrm{Hsu} \mathrm{HC}$, Chiu YL, Chang CF, Liu KF, Su MS, Wang CH, Kou GH (1996a) White spot syndrome baculovirus (WSBV) detected in cultured and captured shrimp, crabs and other arthropods. Dis Aquat Org 27:212-225

Lo $\mathrm{CF}$, Leu JH, Ho $\mathrm{CH}$, Chen $\mathrm{CH}$, Peng $\mathrm{SE}$, Chen YT, Chou $\mathrm{CM}$, Yeh PY, Huang $\mathrm{CJ}$, Chou $\mathrm{HY}$, wang $\mathrm{CH}$, Kou $\mathrm{GH}$ (1996b) Detection of baculovirus associated with white spot syndrome (WSBV) in penaeid shrimps using polymerase chain reaction. Dis Aquat Org 25:133-141

Lo $\mathrm{CF}$, Ho CH, Chen $\mathrm{CH}$, Liu KF, Chiu YL, Yeh PY, Peng SE, Hsu HC, Liu HC, Chang CF, Su MS, Wang CH, Kou GH (1997a) Detection and tissue tropism of white spot syndrome baculovirus (WSBV) in captured brooders of Penaeus monodon with a special emphasis on reproductive organs. Dis Aquat Org 30:53-72

Lo CF, Wang CH, Kou GH (1997b) White spot syndrome (WSS): pathology, hosts and prevalence in captured shrimp and crabs in Taiwan. In: Inui Y (ed) New approaches to viral diseases of aquatic animals. NRIA International Workshop proceedings. National Research Institute of Aquaculture, Nansei, p 206-217

Loh PC, Tapay LM, Lu Y (1997) Quantal assay of shrimp viruses in primary shrimp lymphoid cell cultures. In: Maramorosch K, Mitsuhashi J (eds) Invertebrate cell culture. Science Publishers Inc, Enfield, NH, p 253-259

Loh PC, Tapay LM, Nadala ECB, Lu Y (1998) Some applications of primary cell cultures for the study of penaeid 
shrimp viral pathogens. In: Iizuka T, Kawarabata T (eds) Proceedings of the VIIth International Colloquium on Invertebrate Pathology and Microbial Control, IVth International Conference on Bacillus thuringiensis. Invertebrate Pathology Society, Sapporo, Hokkaida, p 76-83

Lu Y, Tapay LM, Loh PC, Brock JA, Gose RB (1995a) Distribution of yellow-head virus in selected tissues and organs of penaeid shrimp Penaeus vannamei. Dis Aquat Org 23: $67-70$

Lu Y, Tapay LM, Loh PC, Brock JA, Gose RB (1995b) Development of a quantal assay in primary shrimp cell culture for yellow head virus (YBV) of penaeid shrimp. Virmet 52: $231-236$

Murphy FA, Fauquet CM, Bishop DHL, Ghabrial SA, Jarvis AW, Martelli GP, Mayo MA, Summers MD (1995) Virus taxonomy, classification and nomenclature of viruses. Sixth report of the International Committee on Taxonomy of Virus. Archives of Virology, Supplement 10. SpringerVerlag; New York

Nadala ECB Jr, Lu Y, Loh PC (1993) Primary culture of lymphoid, nerve, and ovary cells from Penaeus stylirostris and $P$. vannamei. In Vitro Cell Dev Biol 29A:620-622

Payne CC (1974) The isolation and characterization of a virus from Oryctes rhinoceros. J Gen Virol 25:105-116

Takahashi Y, Itami T, Kondo M, Maeda M, Fujii R, Tomonaga

Editorial responsibility: Timothy Flegel,

Bangkok, Thailand
S, Supamattaya K, Boonyaratpalin S (1994) Electron microscopic evidence of bacilliform virus infection in Kuruma shrimp (Penaeus japonicus). Fish Pathol 29(2):21-125

Tapay LM, Lu Y, Brock JA, Nadala ECB Jr, Loh PC (1995) Transformation of primary cultures of shrimp (Penaeus stylirostris) lymphoid (Oka) organ with simian virus-40 (T) antigen. Soc. Exp Biol Med 209:73-78

Tapay LM, Lu Y, Gose RB, Nadala ECB Jr, Brock JA, Loh $P C$ (1997) Development of an in vitro quantal assay in primarycell culture for a non-occluded baculo-like virus of penaeid shrimp. Virmet 64:37-41

Tsing A, Arcier JM (1989) Hemocytes of penaeid and penaemonid shrimps: morphology, cytochemistry, and hemograms. J Invertebr Pathol 53:64-77

Wang CH, Lo CF, Leu JH, Chou CM, Yeh PY, Chou HY, Tung MC, Chang CF, Su MS, Kou GH (1995) Purification and genomic analysis of baculovirus associated with white spot syndrome (WSBV) of Penaeus monodon. Dis Aquat Org 23:239-242

Wongteerasupaya C, Vickers JE, Sriurairatana S, Nash GL, Akarajamorn A, Boonsaeng V, Panyim S, Tassanakajon A Withyachumnarnkul B, Flegel TW (1995) A non-occluded, systemic baculovirus that occurs in cells of ectodermal and mesodermal origin and causes high mortality in the black tiger prawn Penaeus monodon. Dis Aquat Org 21:69-77

Submitted: January 11, 1999; Accepted: December 13, 1999 Proofs received from author(s): June 2, 2000 